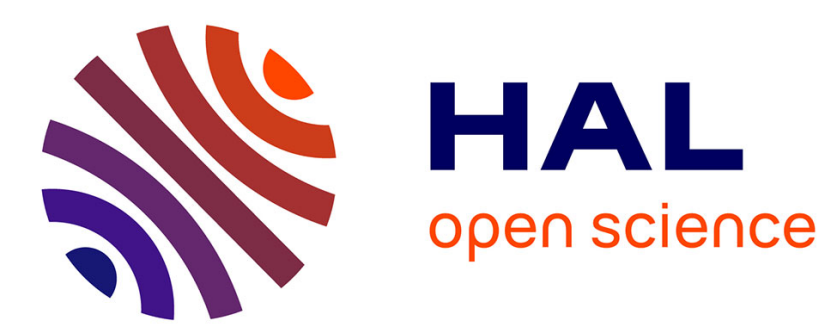

\title{
Influence of Initiation Strength, Ambient Inert Gas, Al-Content and Polymeric Binder on the Detonation Products of High Explosives
}

F. Volk

\section{- To cite this version:}

F. Volk. Influence of Initiation Strength, Ambient Inert Gas, Al-Content and Polymeric Binder on the Detonation Products of High Explosives. Journal de Physique IV Proceedings, 1995, 05 (C4), pp.C4-383-C4-393. 10.1051/jp4:1995431 . jpa-00253736

\section{HAL Id: jpa-00253736 \\ https://hal.science/jpa-00253736}

Submitted on 1 Jan 1995

HAL is a multi-disciplinary open access archive for the deposit and dissemination of scientific research documents, whether they are published or not. The documents may come from teaching and research institutions in France or abroad, or from public or private research centers.
L'archive ouverte pluridisciplinaire HAL, est destinée au dépôt et à la diffusion de documents scientifiques de niveau recherche, publiés ou non, émanant des établissements d'enseignement et de recherche français ou étrangers, des laboratoires publics ou privés. 
JOURNAL DE PHYSIQUE IV

Colloque C4, supplément au Journal de Physique III, Volume 5, mai 1995

\title{
Influence of Initiation Strength, Ambient Inert Gas, Al-Content and Polymeric Binder on the Detonation Products of High Explosives
}

\author{
F. Volk
}

Fraunhofer-Institut für Chemische Technologie (ICT), 76327 Pfinztal, Germany

\section{Introduction}

The knowledge of the reaction products of detonation processes is important for different reasons:

- in order to learn more in the field of kinetics of fast reaction processes, especially with regard to equilibrium or non-equilibrium reactions

- $\quad$ in order to evaluate the completeness of detonation reactions of energetic organic substances or of metallic ingredients such as aluminium (Al), especially as a function of the confinement and the oxygen balance of the explosive charge

- In all of these cases, the detonation products together with the heat output are capable of qualifying the reaction under different conditions.

It is the aim of this investigation to analyze the detonation products of different explosive charges, which were initiated with different initiation stimuli and under different confinements. Confinement influences reaction in so far as it adds resistances to the expansion of the gaseous detonation products and maintains high pressures and temperatures for a longer period of time before lateral rarefactions quench reaction ${ }^{\uparrow}$

In addition, the following points have been investigated:

- the influence of ambient gas and of glass confinement

- $\quad$ and the influence of the Al content and of different polymeric binder systems on the detonation products.

\section{Experiments}

The experiments were conducted in a stainless steel containment with a volume of $1.5 \mathrm{~m}^{3}$. The cylindrical high explosive charge had a mass of about $300 \mathrm{~g}$ with $50 \mathrm{~mm}$ in diameter and 80 to $90 \mathrm{~mm}$ in length. ${ }^{2)}$ For the initiation, different boosters were used:

1) A booster with a weak initiation strength which consisted of $10 \mathrm{~g} \mathrm{RDX}$ (Type I). The cylindrical shape of this booster had a diameter of $20 \mathrm{~mm}$ and a length of also $20 \mathrm{~mm}$. 
2) The second booster type consisted of $18 \mathrm{~g}$ explosive sheets (Type II) with the same diameter as the main explosive charge. It is expected that both boosters, type I together with type II, give rise to a more complete detonation reaction resulting in complete detonation products in such a way that no more explosive components can be identified in the post-blast residue. ${ }^{4)}$

\section{Results}

\subsection{Different Initiation Stimuli}

The results of the examination of the initiation strength of the two different boosters (type I and type I + type II) can be seen in table 1.

\section{Table 1: Influence of a different booster strength on the initiation reaction}

\begin{tabular}{|c|c|c|c|}
\hline \multicolumn{2}{|c|}{ Initiating Booster } & High Explosive Charge & $\begin{array}{c}\text { TNT in Residue } \\
\text { (wt\%) }\end{array}$ \\
\hline $\begin{array}{c}\text { Type I } \\
10 \text { g RDX }\end{array}$ & $\begin{array}{c}\text { Type II } \\
18 \text { g Expl. Sheets }\end{array}$ & $\begin{array}{c}40 \% \text { TNT/60\% RDX } \\
\text { (Compound B) }\end{array}$ & - \\
\hline+ & - & $60 \%$ TNT/40\% NQ & 1.5 \\
\hline+ & - & $50 \%$ TNT/30\% NQ/20\% Mg & 6.0 \\
\hline+ & - & $50 \%$ TNT/50\% AN & 2.0 \\
\hline+ & - & $60 \%$ TNT/40\% NQ & - \\
\hline+ & + & $50 \%$ TNT/50\% NQ & w51.doc \\
\hline- & - & $50 \% \mathrm{TNT} / 50 \% \mathrm{TATB}$ & - \\
\hline+ & + & & \\
\hline
\end{tabular}

In table 1 it is shown that compound $B$, which is much more easily to be initiated, reacts completely also by using booster type $I$ alone. On the contrary, nitroguanidine (NQ) and ammonium nitrate (AN) containing high explosive charges, which need a stronger initiation stimulus, leave unreacted TNT in the post blast residue, which was analyzed by High Performance Liquid Chromatography (HPLC). The same holds for the charge containing magnesium $(\mathrm{Mg})$. On the other side, a complete detonation reaction is shown by using both types of boosters together: No more TNT could be analyzed. 


\subsection{Influence of Ambient Gas and Glass Confinement on the Detonation Products}

When detonating high explosives in different atmospheric conditions, it is of interest to know if the detonation products or the energy out-put will change. In order to investigate this behavior, charges containing $45 \%$ TNT and $55 \%$ Nitroguanidine (NQ) were initiated in the containment under different pressures of argon and in vacuum. In addition, the same charges were conducted which had a glass confinement. In this case, the glass tube exhibited a wall thickness of $9 \mathrm{~mm}$. The results of the unconfined and the glass-tube confined charges are in table 2 and 3.

Table 2: Influence of vacuum and of different argon pressures on the detonation products

\begin{tabular}{|c|c|c|c|c|}
\hline $\begin{array}{l}\text { Sample No. } \\
\text { Ar pressure [MPa] } \\
\text { Composition } \\
\mathrm{O}_{2}-\text { Balance }[\%] \\
\text { Charge Weight }[\mathrm{g}] \\
\Delta \mathrm{H}_{\mathrm{f}}[\mathrm{kJ} / \mathrm{kg}]\end{array}$ & & $\begin{array}{c}1450 / 1 \mathrm{c} \\
\mathrm{Vac} . \\
45 \% \\
331 \\
-661\end{array}$ & $\begin{array}{l}1450 / 2 \mathrm{c} \\
0.05 \\
\mathrm{~T} / 55 \% \mathrm{NQ} \\
-47.6 \\
332 \\
-662\end{array}$ & $\begin{array}{c}1450 / 3 c \\
0.1\end{array}$ \\
\hline Products [mol \%] & $\begin{array}{l}\mathrm{H}_{2} \\
\mathrm{CH}_{4} \\
\mathrm{CO} \\
\mathrm{CO}_{2} \\
\mathrm{~N}_{2} \\
\mathrm{NO} \\
\mathrm{HCN} \\
\mathrm{NH}_{3} \\
\mathrm{C}_{2} \mathrm{H}_{2} \\
\mathrm{H}_{2} \mathrm{O} \\
\mathrm{C}_{5}\end{array}$ & $\begin{array}{c}20.7 \\
0.04 \\
32.1 \\
3.7 \\
27.5 \\
0.1 \\
0.3 \\
0.5 \\
0.02 \\
10.7 \\
4.4\end{array}$ & $\begin{array}{c}8.3 \\
0.1 \\
17.9 \\
7.9 \\
26.1 \\
0.1 \\
3.2 \\
3.0 \\
0.03 \\
19.6 \\
13.8\end{array}$ & $\begin{array}{c}5.0 \\
0.24 \\
14.3 \\
10.3 \\
25.6 \\
0.13 \\
3.6 \\
4.9 \\
0.1 \\
20.0 \\
15.9\end{array}$ \\
\hline $\begin{array}{l}\Delta \mathrm{H}_{\text {det }}[\mathrm{kJ} / \mathrm{kg}] \\
\mathrm{C} \text { in Residue } \\
{[\% \text { of total C] }} \\
\text { Gas formation } \\
\text { [mol/kg] }\end{array}$ & & $\begin{array}{r}2999 \\
10.8 \\
44.5\end{array}$ & $\begin{array}{l}3653 \\
32.2 \\
37.9\end{array}$ & $\begin{array}{l}3763 \\
35.7 \\
35.7\end{array}$ \\
\hline
\end{tabular}




\section{Table 3: Influence of glass confinement \\ on the detonation products}

\begin{tabular}{|c|c|c|c|}
\hline \multirow{2}{*}{$\begin{array}{l}\text { Composition } \\
\text { Sample No. }\end{array}$} & \multicolumn{2}{|c|}{$45 \%$ TNT / $55 \%$ NQ } & \multirow[b]{2}{*}{$1451 / 3$} \\
\hline & $1451 / 1$ & $1451 / 2$ & \\
\hline Ar pressure (Mpa) & Vacuum & 0.05 & 0.1 \\
\hline Oxygen balance $(\%)$ & -47.6 & -47.6 & -47.6 \\
\hline Charge weight (g) & 332 & 335 & 332 \\
\hline$\Delta \mathbf{H}_{\mathrm{f}}(\mathrm{kJ} / \mathbf{k g})$ & -656 & -658 & -658 \\
\hline \multicolumn{4}{|l|}{ Products (mol\%) } \\
\hline $\mathbf{H}_{2}$ & 8.7 & 4.2 & 3.1 \\
\hline $\mathrm{CH}_{4}$ & 0.2 & 0.4 & 0.44 \\
\hline $\mathrm{CO}$ & 15.9 & 10.2 & 9.3 \\
\hline $\mathrm{CO} 2$ & 7.9 & 11.9 & 12.7 \\
\hline $\mathrm{N}_{2}$ & 27.3 & 26.0 & 25.6 \\
\hline No & 0.06 & 0.05 & 0.14 \\
\hline $\mathrm{HCN}$ & 1.35 & 2.4 & 1.1 \\
\hline $\mathrm{NH}_{3}$ & 1.15 & 4.7 & 5.3 \\
\hline $\mathrm{C}_{2} \mathrm{H}_{2}$ & 0.07 & 0.1 & 0.13 \\
\hline $\mathrm{H}_{2} \mathrm{O}$ & 20.5 & 20.7 & 21.0 \\
\hline Cs & 16.8 & 19.2 & 21.3 \\
\hline$\Delta \mathrm{H}_{\text {det }}(\mathrm{kJ} / \mathrm{kg})$ & 3779 & 3960 & 4003 \\
\hline $\begin{array}{c}\mathrm{C} \text { in residue } \\
(\% \text { of total } \mathrm{C})\end{array}$ & 39.8 & 43.3 & 47.2 \\
\hline $\begin{array}{c}\text { Gas formation } \\
(\mathrm{mol} / \mathrm{kg})\end{array}$ & 37.1 & 34.4 & 33.0 \\
\hline
\end{tabular}

w55.doc

From table 2 we see that the detonation products change strongly when going from vacuum to 1,0 bar argon $(0.1 \mathrm{MPa})$ of the unconfined charge. The concentration of $\mathrm{H}_{2}$ und $\mathrm{CO}$ decrease, whereas $\mathrm{CO}_{2}, \mathrm{H}_{2} \mathrm{O}$ and carbon formation increase in the same manner as the detonation heat increases. This means that a detonation under a pressure of 1 bar is much more powerful with regard to the energy output than in vacuum. $^{2)}$

On the other hand, the glass confined charge exhibits already in vacuum detonation products which are similar to those at $0.1 \mathrm{MPa}$ argon of the unconfined charge, as we see comparing table 2 with 3 . But the heat output increases also with higher ambient pressure of 0.05 and $0.1 \mathrm{MPa}$, but not in the same magnitude as before regarding the unconfined charges. As a conclusion we can say that ambient argon of one bar behaves as a confinement. Experiments conducted with 2,0 und 3,0 bar argon exhibited nearly no more further improvement of the confinement. ${ }^{2)}$ 
Composite explosives consisting of polybutadien binder and RDX have shown the same behavior as TNT/NQ when using different ambient pressures of argon as we see in table 4.

Also here increases the heat of detonation very strongly from vacuum to 0.05 MPA argon, because of the increase of $\mathrm{H}_{2} \mathrm{O}$ and $\mathrm{CO}_{2}$ and of carbon via the exothermal Boudouard-reaction

$$
2 \mathrm{CO} \rightleftharpoons \mathrm{CO}_{2}+\mathrm{C} ; \quad \Delta \mathrm{H}=-127,7 \mathrm{~kJ} / \mathrm{kg}
$$

Table 4: Detonation products of PBX - charges

Sample No.

Ar pressure [MPa]

Composition

$\mathrm{O}_{2}$-Balance [\%]

Charge Weight [g]

$\Delta \mathrm{H}_{\mathrm{f}}[\mathrm{kJ} / \mathrm{kg}]$

Products [mol \%]
$\mathrm{H}_{2}$

$\mathrm{CH}_{4}$

$\mathrm{CO}$

$\mathrm{CO}_{2}$

$\mathrm{N}_{2}$

NO

$\mathrm{HCN}$

$\mathrm{NH}_{3}$

$\mathrm{C}_{2} \mathrm{H}_{2}$

$\mathrm{H}_{2} \mathrm{O}$

$\mathrm{C}_{5}$
$\mathrm{HX} 72 / 1$

Vacuum

20\% PB/80\% RDX (10 $\mu \mathrm{m})$

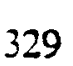

$-94$

33.5

0.1

34.4

1.2

18.8

0.05

0.1

0.5

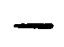

4.8

6.6

15.0

0.7

17.3

3.5

18.0

0.03

0.8

2.9

0.06

19.6

22.2
2949
4214
15.7
49.9
47.3
[\% of total C]
52.1
[mol/kg]
42.0
39.7
$\Delta H_{\text {det }}[\mathrm{kJ} / \mathrm{kg}]$
15.7

(
4440

$\mathrm{HX} 72 / 3$

0.1

330

.95

12.3

2.9

13.1

6.6

18.8

0.02

0.9

2.8

0.5

19.9

22.2 


\subsection{Influence of AI Content on the Detonation Products}

It is very interesting that the detonation of $\mathrm{Al}$ containing $\mathrm{PBX}$-charges with Polybutadiene (PB) binders exhibit a different detonation behavior as to be seen in table 5. In this PBX-charge, consisting of $15 \% \mathrm{~PB}, 15 \% \mathrm{Al}$ and $70 \% \mathrm{RDX}$, we cannot more find the strong influence of vacuum on the detonation products compared with one bar argon $(0.1 \mathrm{MPa})$. The same holds also for the detonation enthalpy, which is not very different for the vacuum shot compared with that of one bar argon.

Table 5: Detonation products of $\mathrm{Al}$ - containing $\mathrm{PBX}$ - charges

Sample No.

Ar pressure [MPa]

Composition

$\mathrm{O}_{2}$-Balance [\%]

Charge Weight [g]

$\Delta \mathrm{H}_{\mathrm{f}}[\mathrm{kJ} / \mathrm{kg}]$

Products [mol \%]
HXA $123 / 1$

Vacuum

$15 \% \mathrm{~PB} / 15 \%$ Al Alcan 400

$56 \%$ RDX Class C/14\% RDX (10 $\mu \mathrm{m})$

0.1

$-69.3$

331

331

$-73$

$-71$

\begin{tabular}{lcc}
$\mathrm{H}_{2}$ & 29.5 & 25.8 \\
$\mathrm{CH}_{4}$ & 0.04 & 1.1 \\
$\mathrm{CO}$ & 26.1 & 20.1 \\
$\mathrm{CO}_{2}$ & 0.01 & 2.7 \\
$\mathrm{~N}_{2}$ & 16.9 & 18.1 \\
$\mathrm{NO}$ & 0.07 & 0.05 \\
$\mathrm{HCN}$ & 0.1 & 2.35 \\
$\mathrm{NH}_{3}$ & 2.2 & 0.9 \\
$\mathrm{C}_{2} \mathrm{H}_{2}$ & 0.04 & 0.3 \\
$\mathrm{C}_{2} \mathrm{H}_{4}$ & 0.03 & 0.2 \\
$\mathrm{H}_{2} \mathrm{O}$ & 4.2 & 7.2 \\
$\mathrm{Al}_{2} \mathrm{O}_{3}$ & 4.6 & 3.9 \\
$\mathrm{Al}$ & 1.6 & 3.0 \\
$\mathrm{C}_{3}$ & 14.6 & 14.3 \\
\hline
\end{tabular}

$\mathrm{K}_{\mathrm{p}}(\mathrm{T})$

?

2.018

Freeze out Temp. [K]

$\Delta \mathrm{H}_{\text {det }}[\mathrm{kJ} / \mathrm{kg}]$

5143

1365

$C$ in Residue

[\% of total C]

\section{6}

34.5

Unreacted Al [\%]

15.0

28.0

Gas formation [mol/kg]

38.6

37.0 
Table 6: Detonation products of HMX / Al / PIB charges with different $\mathrm{Al}$ - content

\begin{tabular}{|c|c|c|}
\hline Sample No.: & PHXA-81 & PHXA-82 \\
\hline Composition, $\%$ & $65 \mathrm{HMX} / 25 \mathrm{Al} / 10 \mathrm{PIB}$ & $60 \mathrm{HMX} / 30 \mathrm{Al} / 10 \mathrm{PIB}$ \\
\hline Ar pressure (MPa) & 0.1 & 0.1 \\
\hline Oxygen balance (\%) & -63.45 & -66.05 \\
\hline Charge mass (g) & 220.0 & 221.5 \\
\hline$\Delta \mathrm{H}_{\mathrm{f}}(\mathrm{kJ} / \mathrm{kg})$ & -96.2 & -119.7 \\
\hline \multicolumn{3}{|l|}{ Products $(\mathrm{mol} \%)$} \\
\hline $\mathrm{H}_{2}$ & 26.1 & 28.9 \\
\hline $\mathrm{CH}_{4}$ & 1.7 & 1.4 \\
\hline $\mathrm{CO}$ & 21.3 & 22.3 \\
\hline $\mathrm{CO}_{2}$ & 3.2 & 2.5 \\
\hline $\mathrm{N}_{2}$ & 20.1 & 18.9 \\
\hline $\mathrm{HCN}$ & 3.2 & 2.6 \\
\hline $\mathrm{C}_{2} \mathrm{H}_{4}$ & 1.7 & 1.4 \\
\hline $\mathrm{H}_{2} \mathrm{O}$ & 3.6 & 2.6 \\
\hline $\mathrm{C}_{\mathrm{s}}$ & 7.1 & 6.9 \\
\hline $\mathrm{Al}_{2} \mathrm{O}_{3}$ & 7.9 & 9.4 \\
\hline $\mathrm{Al}$ & 4.1 & 4.9 \\
\hline$\Delta \mathrm{H}_{\operatorname{det}}(\mathrm{kJ} / \mathrm{kg})$ & 6583 & 7027 \\
\hline $\begin{array}{l}\text { Al in residue } \\
(\% \text { of total } \mathrm{Al})\end{array}$ & 20.8 & 20.6 \\
\hline $\begin{array}{l}\text { C in residue } \\
(\% \text { of total } C)\end{array}$ & 17.7 & 18.0 \\
\hline Gas formation $(\mathrm{mol} / \mathrm{kg})$ & 31.3 & 29.8 \\
\hline
\end{tabular}


Table 7: Detonation products of charges with different binders

\begin{tabular}{|c|c|c|}
\hline Composition, $\%$ & 65 HMX/25 Al/10 PIB & $60 \mathrm{HMX} / 25 \mathrm{Al} / 15 \mathrm{GAP}$ \\
\hline Ar pressure $(\mathrm{MPa})$ & 0.1 & 0.1 \\
\hline Oxygen balance (\%) & -63.45 & -54.40 \\
\hline Charge mass (g) & 220.0 & 328.7 \\
\hline$\Delta \mathrm{H}_{\mathrm{f}}(\mathrm{kJ} / \mathrm{kg})$ & -96.2 & -141.8 \\
\hline \multicolumn{3}{|l|}{ Products (mol\%) } \\
\hline $\mathrm{H}_{2}$ & 26.1 & 30.0 \\
\hline$\overline{\mathrm{CH}_{4}}$ & 1.7 & 0.1 \\
\hline $\mathrm{CO}$ & 21.3 & 26.5 \\
\hline $\mathrm{CO}_{2}$ & 3.2 & 0.2 \\
\hline $\mathrm{N}_{2}$ & 20.1 & 21.6 \\
\hline NO & $?$ & 0.1 \\
\hline$\overline{\mathrm{HCN}}$ & 3.2 & 1.9 \\
\hline $\mathrm{C}_{2} \mathrm{H}_{4}$ & 1.7 & 0.05 \\
\hline $\mathrm{H}_{2} \mathrm{O}$ & 3.6 & 1.0 \\
\hline $\mathrm{C}_{\mathrm{s}}$ & 7.1 & 7.7 \\
\hline $\mathrm{Al}_{2} \mathrm{O}_{3}$ & 7.9 & 10.7 \\
\hline $\mathrm{Al}$ & 4.1 & 0.12 \\
\hline$\Delta \mathrm{H}_{\text {det }}(\mathrm{kJ} / \mathrm{kg})$ & 6583 & 7481 \\
\hline $\begin{array}{l}\text { Al in residue } \\
(\% \text { of total } \mathrm{Al})\end{array}$ & 20.8 & 0.6 \\
\hline $\begin{array}{l}\mathrm{C} \text { in residue } \\
(\% \text { of total } \mathrm{C})\end{array}$ & 17.7 & 21.2 \\
\hline Gas formation $(\mathrm{mol} / \mathrm{kg})$ & 31.3 & 30.1 \\
\hline
\end{tabular}


We assume that an increase of $\mathrm{CO}_{2}$ and $\mathrm{H}_{2} \mathrm{O}$ with increased pressure is prevented by the reaction of these components with Al. This can be explained by the fact that especially $\mathrm{H}_{2} \mathrm{O}$ decreases dramatically with increase of $\mathrm{Al}$, as we see in table 6 , where the detonation products of two plastic bonded explosive charges containing $25 \%$ and $30 \% \mathrm{Al}$ are described. In this case $\mathrm{HMX}$ as explosive component and polyisobutylen (PIB) as a polymeric binder have been used.

\subsection{Influence of the Polymeric Binder on the Detonation Products}

In order to evaluate the influence of different binder systems on the detonation reaction, we investigated two explosive charges containing polyisobutylene (PIB) on the one side, and Glycidylazide polymer (GAP) on the other side. ${ }^{3)}$

The two compositions were as follows:

Charge A: $65 \% \mathrm{HMX}, \quad 25 \% \mathrm{Al}, \quad 10 \% \mathrm{PIB}$

Charge B: $\quad 60 \%$ HMX, $25 \% \mathrm{Al}, \quad 15 \%$ GAP

The main difference between the two charges is the oxygen balance, which is better in the GAP-containing charge $(-54,4 \%)$ compared with $-63,45 \%$ in the PIB containing charge, see table 7 .

Although the enthalpy of formation is less negative and therefore more energetic in Charge $A$ because of the higher $\mathrm{HMX}$ content, the better $\mathrm{O}_{2}$-balance of Charge $\mathrm{B}$ is responsible for a more complete reaction of Al.

In Charge $B$ with the energetic binder we found only $0,6 \%$ of unreacted $\mathrm{Al}$, compared with $20,8 \%$ in Charge $A$.

The more complete Al-reaction leads to a much higher energy output:

Charge B: $\quad 7481 \mathrm{~kJ} / \mathrm{kg}$

Charge A: $6583 \mathrm{~kJ} / \mathrm{kg}$

This means that the $\mathrm{O}_{2}$-balance is very important especially for Al-containing high explosives.

This behavior of different binder systems is easily to understand when we compare the $\mathrm{O}_{2}$-balances of $\mathrm{HMX}$ with GAP, Polybutadien (HTPB) and Polyisobutylen (PIB) as to be seen in table 8 


\section{Table 8: Oxygen balance and enthalpy of formation of different binder systems}

\begin{tabular}{|c|c|c|}
\hline & Oxygen balance (\%) & $\Delta \mathbf{H}_{\mathbf{f}}(\mathbf{k J} / \mathbf{k g})$ \\
\hline GAP & -121.1 & 1179 \\
\hline R 45M (HTPB) & -323.0 & -380 \\
\hline PIB & -342.2 & -1568 \\
\hline $80 \mathrm{RDX} / 20 \mathrm{GAP}$ & & 457.4 \\
\hline $80 \mathrm{HMX} / 20 \mathrm{GAP}$ & -41.5 & 438.5 \\
\hline $80 \mathrm{HMX} / 20 \mathrm{HTPB}$ & -41.5 & 126.9 \\
\hline $80 \mathrm{HMX} / 20 \mathrm{PIB}$ & -81.9 & -110.8 \\
\hline
\end{tabular}

w52.doc

\section{Conclusion}

The influence of different boosters on the initiation of explosive charges containing TNT and nitroguanidine has been investigated. It was found, that a complete detonation was only observed after placing an additional booster sheet with the same diameter as the explosive charge on the front side of the cylindrical charge.

The investigation of Al-containing charges exhibited a very different behavior compared with the charges without Al. No more influence of vacuum or of different ambient gas pressure could be observed.

By comparing two charges with different oxygen balances it was found a great influence on the reaction of $\mathrm{Al}$. The $\mathrm{PBX}$ charge with the better $\mathrm{O}_{2}$-balance containing the energetic GAP-binder reacted nearly complete with the Al, opposite to the charge containing the Polyisobutylene (PIB) binder system. 


\section{References}

1) Donna Price and Frank J. Zerill:

Notes from lectures on detonation physics, Naval Surface Weapons Center, White Oak, Oct. 1981, NSWC MP 81-399

2) F. Volk and F. Schedlbauer:

Detonation Products of Less Sensitive High Explosives Formed under

Different Pressures of Argon and in Vacuum

9th Sympos.(International) on Detonation

August 28 to September 1, 1989, Portland, Oregon, USA

3) F. Volk and F. Schedlbauer:

Products of Al containing explosives detonated in argon and underwater 10th International detonation Symposium, July 12-16, 1993,

Boston, Mass., USA

4) M. Held:

Corner-Turning Distance and Retonation Radius

Propellants, Explosives, Pyrotechnics

14 (1989) 153-161 